Acest articol-ghid încearcă să prezinte obiectiv diferitele proiecte și inițiative personale dedicate patrimoniului digitalizat și reconstituirilor digitale de patrimoniu arhitectural, arătând totodată potențialul, dar și limitările (de moment) ale acestor instrumente de cercetare și explorare. Este esentială dezvoltarea unei metode de lucru pentru a păstra un grad de valoare și de autenticitate a obiectului sau ansamblului înregistrat sau reconstituit. Principiile fundamentale ale lucrului cu patrimoniul arhitectural și responsabilitatea rămân valabile și în mediile digitale. 


\section{digital heritage.}

\section{patrimoniu digitizat}

\section{și digital}





\section{Introducere}

Acest articol se adresează studenților Universității de Arhitectură și Urbanism „Ion Mincu" București și ai celorlalte facultăți de profil autohtone, din toți anii de studiu (I-VI), doctoranzilor, stagiarilor și tinerilor profesioniști din domeniul arhitecturii și al specialităților complementare, care abordează teme de proiectare, de specialitate sau de cercetare despre patrimoniu. Limbajul este așadar simplificat pentru a fi cât mai clar și accesibil.

În continuarea ghidului din proiectul de cercetare Scholar Architect 2020 în care am explorat succint Abordarea istorică în „Metode și tehnici specifice de cercetare în arhitectură" vom prezenta în cele ce urmează ipostaze posibile ale relației între patrimoniu și proiectarea contemporană în contextul (r)evoluției tehnologice. Mai precis ne vom referi la modul în care cele mai recente tehnologii digitale pot fi puse în slujba patrimoniului arhitectural, atât în sfera de educație (formare), cercetare, cât și în cea de intervenție reală (restaurare, conservare și proiectare).

În completarea părții teoretice vom demonstra cum prin proiectul de față Scholar Architect 2021 - Creșterea calității științifice și didactice în învățământul de arhitectură - CNFIS-FDI-2021-0069 - am organizat și coordonat două activități în care să transpunem practic relația între patrimoniul arhitectural și formele digitalizate sau digitale (reconstituiri virtuale) ale acestuia. Este vorba despre Digital Heritage_webinar (seminar online) și Digital Heritage_lab (workshop), desfășurate în luna septembrie 2021, care vor fi detaliate în următoarele capitole.

Expresiile cheie ale acestui mic ghid sunt:

patrimoniu digital (digital heritage)

patrimoniu digitizat (digitized heritage) 
anastiloza virtuală (virtual anastylosis)

experiențe imersive VR și AR (VR \& AR immersive experiences)

acces deschis la conținut cultural de patrimoniu (open acces to heritage cultural content)

\section{De ce discutăm despre patrimoniu digitizat și digital în educația de arhitectură și în practica profesională autohtone?}

Chiar dacă UNESCO definește expresia de patrimoniu digital încă din 2003 prin "Carta Conservării Patrimoniului Digital", evoluția rapidă a tehnologiilor (și contextul pandemic temporar) accentuează relația cu cele mai recente tehnologii, alături de nevoia de a cerceta, disemina informația, explora și interveni cu ajutorul acestora. Acestea declanșează: dezvoltarea de baze de date digitizate, de arhive digitale, de colecții specializate de fotogrametrii, scanarea 3D a monumentelor ca instrument de precizie în intervenția pe obiectul de arhitectură, dezvoltarea de platforme colaborative (internaționale) de lucru de la distanță, muzee și obiective de patrimoniu accesibile prin VR și AR, capacitatea de a diagnostica și realiza patologia unui monument sau de a releva în mod non-invaziv detalii și elemente din structura interioară, altfel inaccesibile observației.

Atât intervențiile pe monument, cât și proiectarea contextuală de arhitectură pot beneficia de aceste instrumente.

Vom explora succint formele de tehnologie care pot sluji patrimoniul prin creșterea nivelului de acuratețe a datelor, pot ajuta calitatea analizei și intervenției, dar și disemina spre un public specializat și larg valoarea acestuia.

Dacă istoria profesiei de arhitect și evoluția arhitecturii în România sunt marcate de momente de sincronizare și desincronizare (Zahariade, Brătuleanu, 2008) cu Vestul Europei, întrerupte de diverse influențe ori caracterizate de introvertire și izolare (1947-1989) ori de îndelungă tranziție, în prezent suntem tot mai ancorați în peisajul internațional. La nivel de educație de arhitectură pe tema patrimoniului - legislație, discurs, specialiști și chiar exemple de bună practică în restaurare și conservare - ne apropiem de un nivel tot mai înalt, dar cu modele punctuale.

La aceste practici contemporane care deja au un grad de maturitate în mediul universitar și profesional internațional putem să ne sincronizăm. Recunoașterea la nivel internațional a diplomei de arhitect obținută în România aduce o deschidere și simultan o nevoie de a ne alinia la exigențe tot mai înalte. Familiarizarea cu aceste tehnologii digitale - în calitate de student și de arhitect diplomat preocupat de patrimoniu oferă un avantaj pe piața (internațională) de servicii de arhitectură.

Este necesară o viziune coerentă la nivel didactic, metode de lucru și cercetare împărtășite atât de atelierul de proiectare, cât și de cele de specialitate (restaurare, conservare). Nivelul universitar și profesional însă trebuie să se facă vizibile prin modele de bună practică în intervențiile 
pe patrimoniu arhitectural autohton la scară mare: în spațiul urban și rural. Aceste modele trebuie promovate, identificat un echilibru clar între doctrine, între restricții și permisivități, cu o bună comunicare și apropiere de publicul larg, precum și de investitori și de mediul politic. Arhitectura și mai ales patrimoniul arhitectural ale unui stat, reprezintă elemente de identitate, putere și atractivitate economică și estetică, care trebuie valorificate și valorizate ${ }^{1}$.

Mai departe, încă din timpul formării universitare și apoi ca arhitecți avem misiunea de a fi oameni de cultură, intelectuali și deopotrivă buni practicieni ai profesiei, care să educe gustul publicului larg și să ajute la îmbunătățirea calității vieții. În acest sens, dacă ne dorim un spațiu autohton cu intervenții de bună calitate pe patrimoniu arhitectural (dar și urban, arheologic sau peisajer) este nevoie să comunicăm foarte bine. Arhitectura însăși este un limbaj prin care comunicăm, după cum afirmă și descrierea cursului de Limbaj Arhitectural II, din Universitatea de Arhitectură și Urbanism „Ion Mincu”, una dintre disciplinele pe care le îndrum: „Înțelegem arhitectura ca pe un limbaj al formelor semnificante cu ajutorul cărora omul remodelează existentul, și nu ca simplu act de comunicare, nici ca act pur estetic."(Criticos, 2021).

Este vorba așadar despre responsabilitate, dar și dialog inteligent și echilibrat cu trecutul, creativitate și chiar inovație.

Percepția publicului larg, dar și din interiorul breslei autohtone asupra patrimoniului trebuie să fie aceea de bun „activ" (asset), nu „pasiv" (liability), așa cum am susținut într-o prelegere și articol prezentat la New York în 2018 (Zacharias Vultur, 2018, p. 18). Orașele, satele și peisajul cresc organic în întrepătrundere cu diferitele forme de patrimoniu construit, ceea ce pe termen lung este o invitație la creativitate și inovație, atât artistică, cât și științifică (tehnică).

Din cele mai vechi timpuri arhitectura a fost influențată mai discret sau mai puternic de (r)evoluțiile tehnice și tehnologice, uneori începând de la nivel imaginar, ilustrată în literatura de anticipație și în artele vizuale, iar apoi transpusă și în vocabularul de specialitate și în construcție. Am investigat aceasta temă în teza mea de doctorat "Metafora mașinii în discursul modern de arhitectură. Le Corbusier și Norman Bel Geddes", (2012). În ceea ce privește patrimoniul arhitectural, încă din Epoca Luminilor, în secolele al XVII-lea și al XVIII-lea, marea „Epocă a Rațiunii”, „Interesele moderne pentru patrimoniu și conservarea sa au fost mereu strâns legate de științe și abordarea științifică [ ... ] ... științele trebuie să fie folosite ca «unealtă» în concordanță cu cerințele diferitelor sarcini care apar în conservare. Rolul științei este să asiste în analizarea autenticului, a materialului istoric al unei astfel de opere." (Jokilehto, 2018, pp. 291-292).

1 În discursul despre patrimoniul "valorificat” și „valorizat” al membrelor Echipei ARCHE în cadrul prelegerilor pentru școala de vară „Schonberg Live Studio 2021”, desfășurate la Dealu Frumos, jud. Sibiu în perioada 16-29 august 2021, la Casa Verde și la Centrul de Studii de Arhitectură Vernaculară, coordonator științific asist.dr.arh. Ioana Zacharias Vultur, alături de echipa de organizare, proiect finanțat din Timbrul de Arhitectură, Filiala OAR Sibiu-Vâlcea. 
Filosoful american Thomas Kuhn² dezbate poziția științei în relație cu istoria în cartea sa Structure of Scientific Revolutions (Structura revoluțiilor științifice), publicată prima oară în 1962. Autorul observă un tipar non-liniar de respingere a științei de către comunități, de fiecare dată când aceasta avansa puternic, deoarece "introducea un nou mod radical de a vedea natura și comportamentul materialelor" (Jokilehto, 2018, p. 292). De asemenea, Kuhn definește „revoluția științifică” în cercetare ca fiind un moment în care aceasta intră în criză din cauza metodelor care nu mai oferă răspunsuri satisfăcătoare la fenomene nou apărute. Așadar revoluția științifică este o înlocuire a unei paradigme vechi cu una nouă, cu metode de cercetare și un set de reguli noi. Desigur Kuhn se referă cu precădere la cercetarea în fizică ori chimie, dar aceste revoluții și descoperiri influențează inclusiv arhitectura și tehnicile de conservare și restaurare în epoca modernă.

Prin analogie, dezvoltarea științei tehnologiilor digitale afectează gradual lucrul cu toate formele de patrimoniu cultural și generează inclusiv o nouă categorie: patrimoniul digital. Ca în cazul oricărei creații umane noi și a "puterii" acesteia este esențial să utilizăm doar avantajele și să eliminăm tot ceea ce poate fi negativ. De aceea, specialiștii definesc cu responsabilitate metodele de cercetare, setul de reguli și principii, dar și valorile pe baza cărora noile tehnologii digitale sunt utilizate în lucrul cu patrimoniul.

\section{Definiții}

Este esențial să începem de la definiția expresiei Digital Heritage și a compoziției sale, așa cum apare în viziunea UNESCO.

\section{Conform "Charter on the Preservation of the Digital Heritage"}

(Carta pentru Prezervarea Patrimoniului Digital) din 17 octombrie 2003, republicată într-un document UNESCO din 2009:

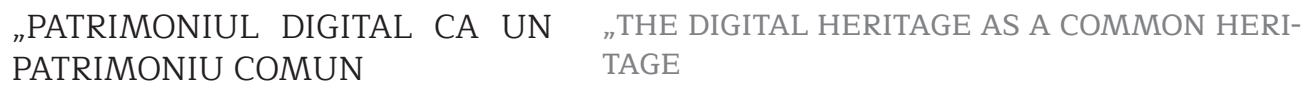

Articolul 1

Article 1

\section{Scop}

Patrimoniul digital constă în resurse unice de cunoaștere și expresie umană. Cuprinde resurse culturale, educaționale, științifice și administrative, precum și tehnice, legale, medicale și alte tipuri de informație creată digital, sau convertită în formă digitală din resurse analoage

Scope

The digital heritage consists of unique resources of human knowledge and expression. It embraces cultural, educational, scientific and administrative resources, as well as technical, legal, medical and other kinds of information created digitally, or converted into digital form from existing analogue resources. Where resources are "born digi-

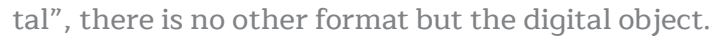
Digital materials include texts, databases, still and

2 Thomas Kuhn (1922-1996) este unul dintre cei mai influenți filosofi ai științei secolului al XX-lea, cartea sa The Structure of Scientific Revolutions (1962) fiind una dintre cele mai citate cărți din toate timpurile. Alături de doctrinele sale, Kuhn se consideră că a inaugurat un nou stil în filosofia științei. 
moving images, audio, graphics, software and web pages, among a wide and growing range of formats. They are frequently ephemeral, and require purposeful production, maintenance and management to be retained. Many of these resources have lasting value and significance, and therefore constitute a heritage that should be protected and preserved for current and future generations. This ever-growing heritage may exist in any language, in any part of the world, and in any area of human knowledge or expression."

(Charter on the Preservation of the Digital Heritage, 2009, p.2) existente. Acolo unde resursele "sunt născute digital", nu există alt format decât obiectul digital. Materialele digitale includ texte, baze de date, imagini statice și în mișcare, audio, grafice, software și pagini web, într-o amplă și în creștere gamă de formate. Sunt frecvent efemere, și necesită o producție cu sens, mentenanță și management. Multe dintre aceste resurse au valoare și semnificație durabile, și de aceea constituie un patrimoniu care trebuie protejat pentru generațiile prezente și cele viitoare. Acest patrimoniu în creștere poate exista în orice limbă, în orice parte a lumii, și în orice arie de cunoaștere și expresie umană."

Așadar este vorba atât despre ceea ce este "născut digital" (born digital), cât și ceea ce este „digitizat după o sursă analogă”. Exista așadar forme de patrimoniu digital provenite din patrimoniu digitizat precum reconstituirile digitale de artefacte până la ansambluri arheologice, arhitecturale și urbane pe baza documentelor analogice: desene, planuri, hărți, texte tipărite, lucrări de artă, diverse documente din arhivele clasice, etc.

Formele de patrimoniu digital înseamnă conform definiției de mai sus dată de UNESCO atât "resurse create digital, cât și convertite într-o formă digitală din surse analoage existente". În acest articol-ghid ne vom referi la patrimoniul digital rezultat din reconstituirile virtuale de arhitectură după monumente.

Patrimoniul digital "este compus din materiale de valoare durabilă generate de computer [...] și emană din diferite comunități, industrii, sectoare și regiuni. Nu toate materialele digitale sunt de valoare durabilă [...], așa cum se afirmă în articolul "Concept of Digital Heritage", pe site-ul UNESCO: https://en.unesco.org/themes/information-preservation/digital-heritage/concept-digital-heritage.

În concluzie este vorba despre două tipuri de relație între patrimoniu și tehnologiile digitale de ultimă oră, fiecare putând să reprezinte un ajutor în prezervarea acestuia (arhivare, scanare, înregistrare și măsurare digitală, etc.) și conservare pentru generațiile viitoare (prin tehnologii de investigare, dar și prin transmiterea într-o formă digitizată, inclusiv prin reconstituiri, etc.). Despre acestea am vorbit în prelegerea cu titlul „VR in the service of Architectural Heritage / VR în slujba patrimoniului arhitectural", în cadrul Conferinței Tech4Culture, desfășurată la Institutul Francez, Sala Elvire Popesco, la 3 martie 2020. 


\section{Raportarea la obiectivele didactice ale UAUIM}

În contextul creșterii preocupării pentru patrimoniul arhitectural în curricula activității de atelier de proiectare a Universității de Arhitectură și Urbanism „Ion Mincu” încă din anul I, transferul de cunoștințe dinspre Departamentul de Istoria și Teoria Arhitecturii și Conservarea Patrimoniului este înlesnit.

$\mathrm{Cu}$ sprijinul seminariilor, prelegerilor și al disciplinelor specializate, poate fi conturată o formare continuă, graduală ca nivel de înțelegere și abordare critică, a chestiunii patrimoniului.

Temele de atelier de restaurare și conservare, de proiectare, de diplomă și de cercetare doctorală care intervin pe un monument sau realizează inserții în situri protejate au în structură deja etape de lucru realizate pe baza unor documente digitizate (scan-uri după relevee, planuri urbanistice, desene, fotografii vechi, documente de arhivă - text, hărți, etc.) și prin urmare folosesc câteva programe convenționale de proiectare pentru vectorizare, marcarea patologiei degradărilor, a valorilor și gradelor acestora, și pentru propunerea de intervenție de arhitectură, de structură, de restaurare și conservare. Așadar acestea sunt mai degrabă reprezentări după date obținute analog, iar valoarea acestor piese desenate este mai degrabă una de explicare grafică, decât științifică.

Pentru a crește acuratețea datelor și calitatea detaliilor însă, există câteva tehnici și tehnologii care introduc informații științifice și frecvent detalii care prin metode non-invazive ar rămâne ascunse: fotogrammetria 3D, scanarea 3D, LiDAR (care a revoluționat cercetarea de arheologie), tehnologiile GIS de colectare de date și de mapare, instrumentele de măsurare a umidității sau temperaturii pentru construcții și lucrpri de artă (fresce, de pildă), etc.

\section{Cum pot cele mai recente tehnologii să fie un ajutor pentru educația și practica profesională contemporane de arhitectură?}

Acestea pot deveni un ajutor - pe lângă programele convenționale pe computer, deja utilizate - în educația de arhitectură la atelierele de restaurare și conservare, dar și în practica de specialitate, deoarece deja putem vorbi despre o "maturitate" a acestor tehnologii în lucrul cu patrimoniul material în toate formele sale, de la scara unui artefact la mari ansambluri urbane și situri arheologice. Desigur acestea trebuie utilizate cu responsabilitate, păstrând accentul pe criteriile de valoare și autenticitate ale patrimoniului, în orice etapă de analiză și unde e cazul, reconstrucție digitală.

Este vorba așadar de aducerea de mai multă precizie, dar frecvent și de detalii noi în înțelegerea unui monument, așa cum vom exemplifica în cele ce urmează. Aceste instrumente nu înlocuiesc cunoașterea pe sit a situației, principiile cartelor de restaurare și conservare și nu reprezintă adevăruri absolute, ci doar o etapă tehnică mai evoluată. 


\section{Criterii esentiale și metode de lucru cu patrimoniul digitalizat și digital (reconstituirile virtuale după monumente de arhitectură)}

\section{Autenticitatea}

Reamintim aici două dintre principiile de restaurare care se referă la criteriul autenticității, așa cum le-am prezentat în "Metode și tehnici specifice de cercetare în arhitectură", în capitolul despre „Abordarea istorică":

„Restaurarea, ART. 9: Procesul restaurării este o operație extrem de specializată. Scopul ei este de a păstra și revela valoarea estetică și istorică a monumentului și se bazează pe respectul materialului original și a documentelor autentice." (Carta de la Veneția, 1964)

În ceea ce privește patrimoniul digitizat, acest principiu al autenticității este respectat în mare măsură sau chiar absolut deoarece prin procesul de digitizare nu se deformează sau distorsionează informația (intenționat), iar dacă există neconcordanțe, acestea provin de la sursele primare în sine. Un exemplu ar fi neconcordanțe între proiectul inițial (de autorizație) al unui monument de arhitectură, releveul clasic cu măsuratori prin metode convenționale și scanarea 3D a acestuia. Acestea pot să apară din modificări ale monumentului construit față de proiectul desenat (din varii motive - economice, probleme tehnice descoperite în timpul construcției, compromisuri stilistice sau de materiale de construcție, etc.) sau din erori de releveu convențional față de scanarea 3D sau 4D. Prin urmare aceste piese sunt autentice și pot fi văzute fiecare în sine ca „verificări” ale arhitecturii și stării unui monument din mai multe perspective, inclusiv cu descrieri în text, fotografii sau chiar opere de artă plastică care îl descriu. Proiectul final de restaurare, conservare și intervenție de arhitectură realizat pe baza acestor piese trebuie să fie așadar o cercetare rafinată a tuturor acestor straturi de informație, pentru a avea cât mai multă precizie și un grad cât mai mare de autenticitate, prin urmare a păstra valoarea monumentului.

\begin{abstract}
"Restoration should aim to re-establish the potential oneness of the work of art, as long as this is possible without committing artistic or historical forgery, and without erasing every trace of the passage through time of the work of art."
\end{abstract}

(Brandi, 2005, p. 50)
"Restaurarea trebuie să țintească re-stabilirea unității lucrării de artă, atât timp cât este posibil fără a comite fals artistic sau istoric, și fără a șterge orice urmă a trecerii prin timp a lucrării de artă."

Acest scurt citat din cunoscuta lucrare Teoria Restaurării de Cesare Brandi ridică două chestiuni în privința patrimoniului digital rezultat din îmbinarea între cel digitizat și părți „născute digital”, aspecte tratate de un articol foarte recent publicat de cercetători din două instituții internaționale recunoscute - Institutul pentru Tehnologii Aplicate Patrimoniului Cultural, CNR, Roma, Italia și Universitatea LUND, Departamentul de Arheologie și Istorie Antică \& Laboratorul de Ștințe Umaniste, LUND, Suedia: conceptul de „anastiloză virtuală”, posibilele limitări 
de interpretare și necesitatea definirii unei metode de lucru. Articolul este intitulat "Reconstructing the original splendour of the House of Caecilius Iucundus. A complete methodology for virtual archeology aimed at digital exhibition.” („Reconstruind splendoarea originală a locuinței lui Caecilius Iucundus. O metodologie completă pentru arheologie virtuală pentru o expoziție digitală.") - așadar un sit antic și cunoscut din Pompeii - și începe de la discuția despre „corectitudinea filologică unei astfel de reconstrucții bazate pe diferite tipuri de surse precum "picturi, desene, texte tehnice și literare, comparații și a utilizării modelelor 3D integrate - bazate pe realitate (reality-based) și bazate pe surse (source-based)" (Demetrescu et alii, 2016, p. 51).

Primul obiectiv al proiectului a fost de a "releva, înregistra și analiza un întreg cartier Pompeian, Insula VI" și cel de-al doilea, de a „investiga cum utilizarea de astfel de documentații ar putea influența efortul arheologic de a defini imaginea originală a clădirilor care compuneau insula" (Demetrescu et alii, 2016, p. 52). Dacă „anastiloza” reprezintă reconstituirea unui obiect distrus parțial utilizând elemente arhitecturale originale pe cât posibil (tehnică utilizată și în restaurarea de ceramică sau alte obiecte mici), anastiloza virtuală ("virtual anastylosis") este reconstituirea bazată parțial pe elemente și măsurători aflate in situ și pe elemente non in situ, cum ar fi reprezentări prin acuarelă ale ansamblului, interpretarea fotografiilor vechi, ale unor machete din ipsos, desene tehnice din secolul al XIX-lea etc. Pentru a crea o metodă de lucru, creatorii proiectului utilizează un tabel care încearcă să sintetizeze tipurile de surse utilizate în reconstituirea virtuală a ansamblului Pompeian: surse obiective (ruine aflate in situ, modelul 3D scanat cu laser scanner-ul TOF, fresce și elemente arhitecturale extrase ale căror poziție orginală e cunoscută și ortofotogrammetrii) și surse interpretate (din studii științifice - baze de date de arheologie, cărți publicate, etc., din mărturii - fotografii vechi ale frescelor dispărute și cu starea de conservarea din prima jumătate a secolului al XX-lea, acuarele de secol XIX, desene tehnice de secol XIX-XX, etc. și paralele și analogii teoretice cu picturile aflate in situ, cu scheme decorative specifice pentru Pompeii, etc.). Așadar subiectul autenticității este aici privit din perspectiva unor posibile limitări de interpretare determinate de două tipuri de surse cele aflate in situ și cele non in situ - de corelarea corectă a pozițiilor lor în spațiu (mai precise sau mai relative, în funcție de sursă), de posibile deformări sau reprezentare artistică a surselor (fotografie, acuarelă), dar și de precizia descrierilor din texte.

De aceea autorii acestei cercetări și acestui articol au dezvoltat o metodă de lucru, un așa-numit "workflow”, care să explice exact pașii de urmat, modalități de verificare și cum reconstituirea virtuală a acestui cunoscut sit arheologic din patrimoniul mondial să reușească să fie cât mai curățată de imprecizii, să aducă un grad ridicat de informație și chiar să indice elemente noi, altfel inaccesibile cu instrumentele clasice de măsurători. Articolul ilustrează foarte bogat și explică un proces de lucru într-o abordare realistă, indicând diversele tehnologii performante utilizate, relația posibilă între surse analoage digitizate și digitale, limitări (de moment) și beneficii. 
Prin utilizarea unor aparate și tipuri de investigații cu soft-uri de ultima generație - scanare 4D, soft-uri ca Blender, Cloudcompare sau Meshlab pentru vizualizarea morfologiei ori Metashape pentru fotogrammetrie, 3DHOP ca platformă online de diseminare și lucru online - detalii interne din etapele evolutive, altfel ascunse privirii și imposibil de observat $\mathrm{cu}$ metode non-invazive, au putut fi descoperite.

În concluzie, un astfel de exemplu ilustrează stadiul la zi al cunoașterii și posibilităților de îmbinare dintre metodele convenționale, sursele de patrimoniu digitizate și cele născute digital prin care este abordat criteriul autenticității în reconstituirea virtuală a unui monument istoric, în acest caz de patrimoniu arheologic.

\section{Valoarea}

Dacă despre acest criteriu și respectarea sa în intervențiile în situri de patrimoniu sau pe monumente istorice am discutat succint în capitolul despre "Abordarea istorică" din Proiectul SCHOLARH 2O2O, aici îl vom pune în relație cu formele de patrimoniu digitizat și digital, așadar cele convertite după surse analoage și cele născute digital.

Așa cum reiese din definițiile de mai sus din Charta pentru Prezervarea Patrimoniului Digital, „Multe dintre aceste resurse au valoare și semnificație durabile, și de aceea constituie un patrimoniu care trebuie protejat pentru generațiile prezente și cele viitoare."(Carta Prezervării Patrimoniului Digital, 2009, p. 2). Prin urmare nu toate resursele au valoare și semnificație durabile. De aceea ce este creat digital în scopul prezervării patrimoniului și a transmiterii sale în timp trebuie să nu aducă prejudicii de valoare ori imagine monumentului și să fie în sine un tip de resursă valoroasă, prin calitatea realizării, prin ceea ce aduce ca plus-valoare cunoașterii de până atunci și chiar imaginii (poate necunoscute de pildă a unui ansamblu reconstituit), etc.

Așadar este important să ne asumăm responsabilitatea utilizării sau creării unor resurse digitale atunci când este vorba despre patrimoniu, să nu deformăm realitatea construită, să fim obiectivi și preciși.

Acesta ar fi modul de lucru prin care tehnologiile digitale pot veni în sprijinul patrimoniului, augmentându-i valoarea memorială, afectivă, istorică, estetică. De asemenea, tehnologiile digitale pot ajuta inclusiv la salvgardarea unui monument ori ansamblu de arhitectură sau arheologie aflat în pericol natural sau creat de om, așadar trebuie utilizate cu măsură și echilibru.

\section{Studiu de caz-model}

Un exemplu de studiu și proiect care adaugă valoare păstrând în același timp autenticitatea unui sit de patrimoniu este ilustrat de articolul "World Heritage, vernacular dwellings and digitalisation: the case of the Fortified Churches in Transylvania, Romania" / "Patrimoniul mondial, locuințele vernaculare și digitalizarea: cazul Bisericilor Fortificate în Transilvania", publicat în ediția din 2020 a revistei anuale a UAUIM, 
CSAV Journal, pe care o coordonez. Autorii, personalități recunoscute în protejarea patrimoniului arhitectural vernacular și experți UNESCO de la Escuela Superior Gaellicia, Portugalia și Universitat Politecnica de Valencia, Spania prezintă proiectul 3D Past "creat pentru a pune în lumină Patrimoniul Vernacular Mondial din Europa", dezvoltat mai departe în proiectul „Living and virtual visiting European World Heritage", în cadrul Programului Europa Creativă al Comisiei Europene și desfășurat între 2016-2020 de către aceste două instituții mai susmenționate.

Scopul declarat al acestui proiect de cercetare și reconstituire este de a „studia și valorifica valoarea inestimabilă a acestor așezări vernaculare", "de a învăța cum autenticitatea acestora este păstrată" și de a "face accesibile în mod virtual cetățenilor locuri aparținând Siturilor Patrimoniului Mondial" (Correia et alii, 2O2O, p. 15).

Proiectul s-a concentrat pe 8 situri de patrimoniu vernacular mondial selectate, printre care la poziția 5 regăsim și „Villages with Fortified Churches in Transylvania, Romania" - Satele cu Biserici Fortificate din Transilvania, România. Selecția „are intenția de a putea fi replicată abordarea, în viitor, în alte situri din Europa și din întreaga lume." (Correia et alii, 2020, p. 16).

Din întregul demers complex, ne vom concentra pe a observa pe scurt tipurile de surse utilizate, metodele și rezultatele obținute, date care să ilustreze o manieră de lucru cu patrimoniul digitizat și cel digital.

\section{Metoda}

După cercetarea acestor situri, a elementelor de patrimoniu arhitectural vernacular și a geografiei acestor locuri s-au creat o platformă digitală https://www.esg.pt/3dpast/platform/ - și o aplicație cu realitate virtuală (VR) și augmentată (AR). Cazul Satelor Săsești este prezentat pe aceasta pagina a platformei - https://www.esg.pt/3dpast/platform/transylvania. html - și conține modele 3D de case și de ansambluri de case, planuri de ansambluri fortificate, planuri de case, desene tehnice care explică configurația spațială tipică, detalii tehnice de îmbinări specifice, de structură, precum și fotografii de pe sit și cu echipele de cercetare și restaurare pe teren, precum și imagini de atmosferă și culoare locală (Fig. 1).

Elementele de AR și VR sunt accesibile prin dispozitive mobile și platforme web, iar una dintre experiențele interactive constă „într-o suprapunere în timp real între imagini istorice și observație reală [...] care să dea vizitatorului o percepție senzorială a evoluției sitului" (Correia et alii, 2020, p. 32).

În concluzie acest proiect accesibil prin caracterul său digital este un model de implementare, de îmbinare între surse analoage și surse născute digital. Obiectivul este de a pune și mai mult în valoare situri de patrimoniu mondial, de a la face accesibile spre un public mai larg care să le perceapă ca o moștenire colectivă. 


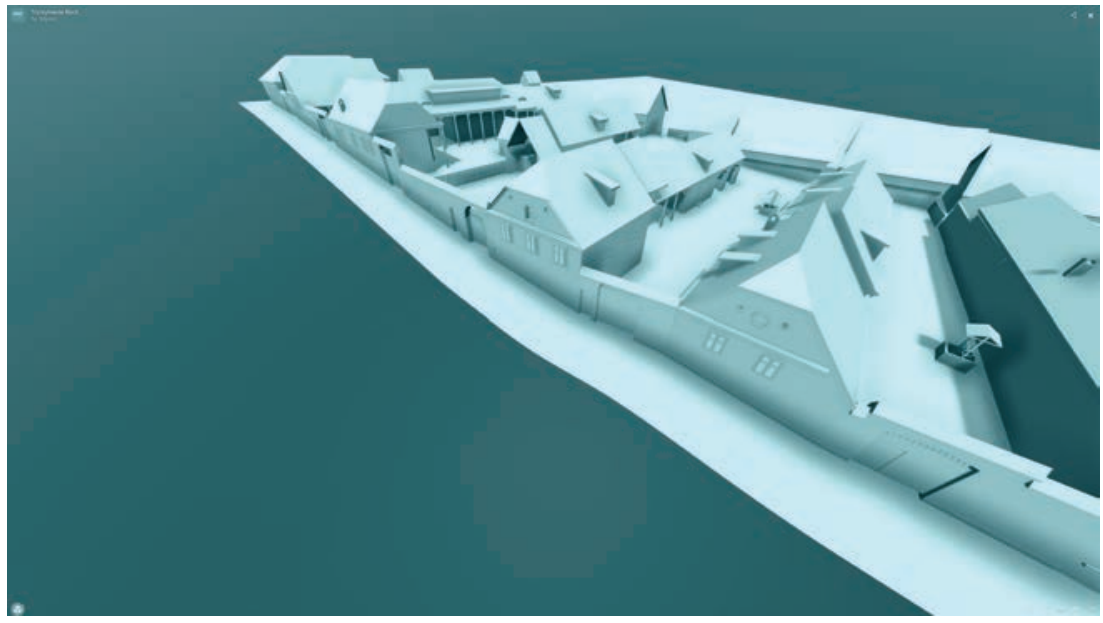

Fig. 1. Imagine 2D cu unul dintre modelele 3D de pe platforma digitală a proiectului 3D Past.

Reconstrucția virtuală reprezintă o configurație spațială specifică satelor săsești din Transilvania, în care se poate observa organizarea funcțională și relația constructivă între case. Sursa imaginii: https://www.esg.pt/3dpast/platform/transylvania.html

\section{Patrimoniul digital de arhitectură}

\section{Argument}

Profesorul american Edgar DALE propune în 1946 un model devenit cunoscut în istoria metodelor pedagogice - Conul experienței (sau Piramida învățării) (Fig. 2). Această schemă arată cum înțelegerea și capacitatea unui student (sau individ în general) de a-și aminti informația cresc direct proporțional cu cât activitatea este mai practică, experiența mai reală și sunt solicitate mai multe simțuri. Transpus în educația de arhitectură, atelierul, stagiile de practică, vizitele, excursiile, workshop-urile și școlile de vară - susțin exact această direcție esențială. La acestea se adaugă și experiențele imersive realizate cu ajutorul tehnologiilor VR și AR, prin care de pildă se poate explora un monument de arhitectură sau învăța istoria arhitecturii și a artei. Aceste medii virtuale permit „vizitarea de la distanță”, dar și „observarea unor detalii” altfel inaccesibile la o parcurgere reală a unei clădiri, precum elemente aflate pe un tavan înalt pictat, un detaliu de frescă, etc.

Cele mai recente aplicații de realitate virtuală (VR) pentru arhitectura de patrimoniu fac apel la kinestezie, la categoria „simularea experienței reale", așadar au șanse foarte mari de a ajuta la memorarea și înțelegerea unui spațiu, mai ales interior, conform principiului lui Dale.

\section{Studiu de caz-model}

Cel mai relevant exemplu în acest sens este modul în care tehnologiile VR și AR șunt folosite pentru a pune în valoare Palatul Versailles, ansamblu înscris pe lista UNESCO încă din 1979, aparținând așadar de patrimoniul mondial. 
În 2019, Palatul Versailles și Google Arts \& Culture lansează pe baza unui parteneriat "VersaillesVR: the Palace is Yours”, o aplicație de realitate virtuală, realizată cu ajutorul fotogrammetriei 3D (mii de fotografii), prin care întregul palat poate fi vizitat liber, care face apel la diferite simțuri, este asistat de comentarii ale echipei științifice pentru peste 150 de lucrări de artă și posibilitatea de a pătrunde în locuri și a vedea detalii altfel inaccesibile.

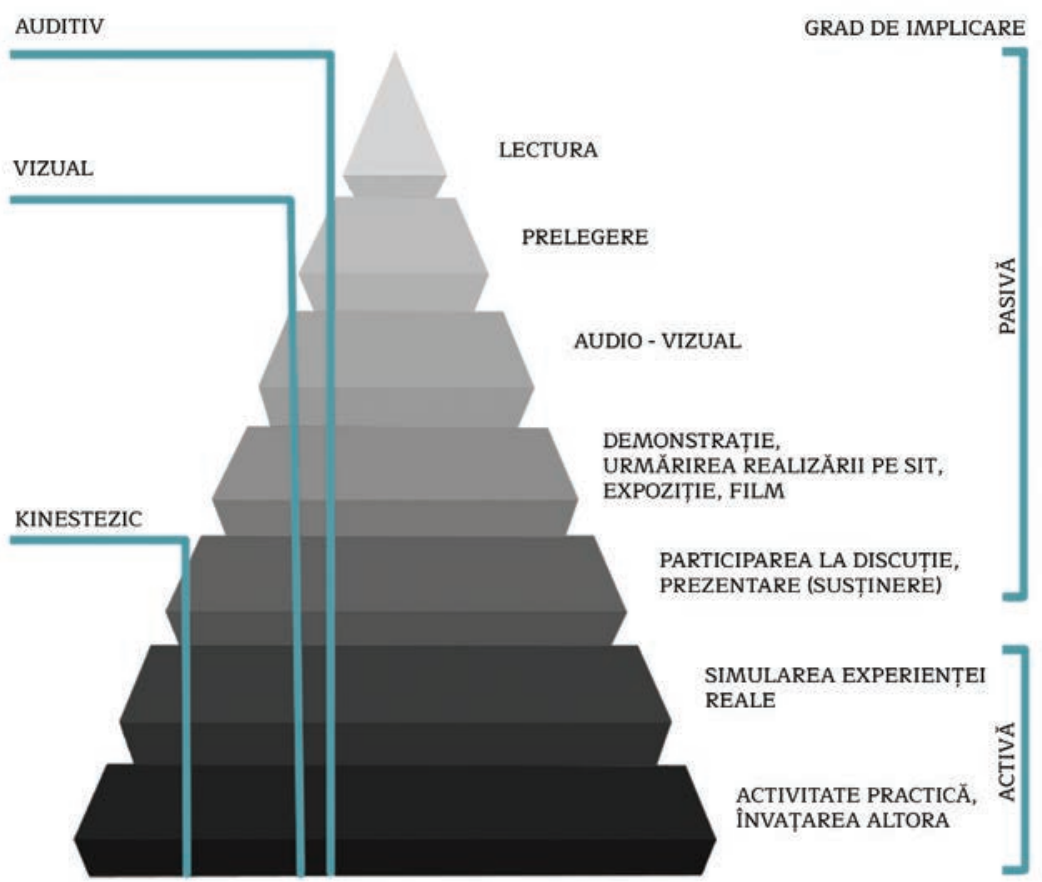

Fig. 2. Diagramă după „Conul experienței” sau „Piramida învățării” de Edgar Dale, $1946^{\prime \prime}$.

Sursa imaginii: arhiva personală, prelucrare după Dale (1969).

De aceea unul dintre speakerii internaționali invitați la Digital Heritage_webinar (15 septembrie 2021) a fost Paul Chaine, șeful Departamentului Digital al Palatului Versailles, profesor la Sciences Po Paris și ESCP Business School. În discursul său a vorbit despre proiectele Palatului Versailles cu ajutorul tehnologiilor VR și AR în scop educativ, de accesibilitate și democratizare a cunoașterii. În perioada contemporană, muzeele trebuie să se adapteze la fenomene noi și să se deschidă și în alte moduri pentru a se menține și rămâne atractive pentru un public tot mai diversificat. Aceste procese de reinventare necesită însă multă responsabilitate, și creativitate în lucrul cu conținut de patrimoniu cultural.

Concret, aplicația de VR "VersaillesVR: the Palace is Yours" (Fig. 3) poate fi descărcată de pe platforma Steam și experimentată cu aju- 
torul căștilor de VR HTC Vive, Oculus Rift sau Valve Index: https:// en.chateauversailles.fr/news/life-estate/versaillesvr-palace-yours\#aunique-visit.

Comparând vizitele pe care le-am făcut la Palatul Versailles în realitate cu cea virtuală în VR se poate afirma că: senzația de experiență reală este foarte asemănătoare (lumina naturală, sunetul pașilor, realismul și precizia imaginilor rezultate din fotogrammetrie la nivel de culori și texturi), dar este mult mai intimă (utilizatorul este singur în spațiul Palatului, fără alți vizitatori sau ghizi), informațiile și comentariile pentru lucrările de artă pot fi accesate foarte ușor, detalii altfel inaccesibile pot fi văzute de aproape sau din alte unghiuri, ceea ce doar un restaurator care ar interveni pe o frescă ori ornament (de pe tavanele înalte de pildă) ar putea observa.

\section{Put on your headset and be transported to the Hall of Mirrors during the night-time.}

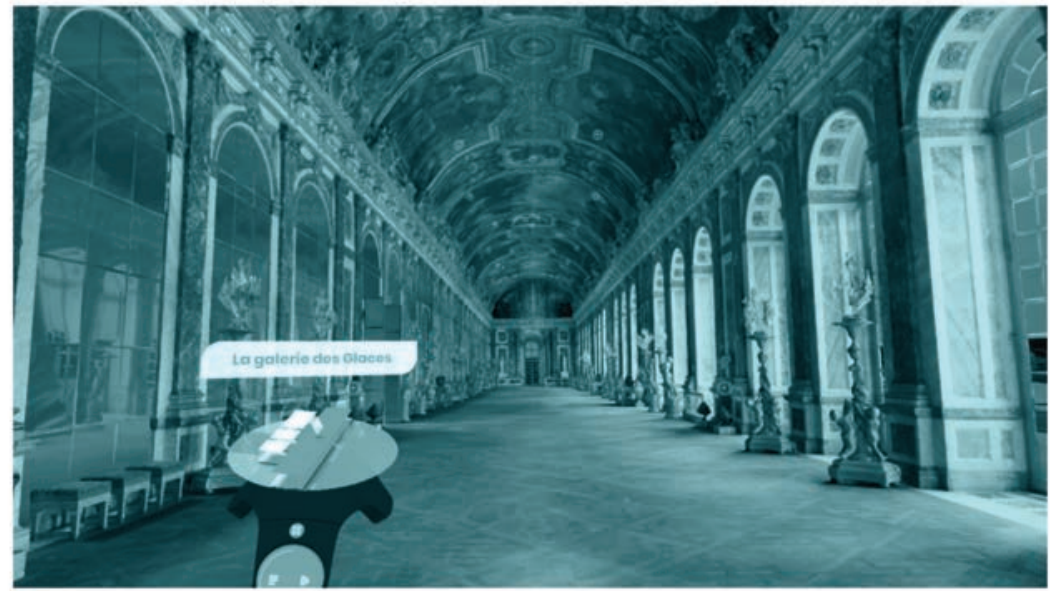

Hall of Mirrors in VersaillesVR: the Palace is Yours. (c) Château de Versailles, 2019,

Fig. 3. Secvență din turul VR al Sălii Oglinzilor din proiectul „VersaillesVR: the Palace is Yours".

Aici volumetria și aspectul real sunt obținute prin tehnica fotogrammetriei 3D, la care sunt adăugate diverse elemente de interactivitate și senzorial: sunetul pașilor, posibilitatea de a atinge suprafețe, de a te apropia, de a auzi sau citi informații, de a vedea detalii deosebite sau altfel innaccesibile la o vizită reală (de ex. tavanele pictate). Sursa imaginii: https://en.chateauversailles.fr/news/life-estate/versaillesvr-palaceyours\#a-unique-visit (c) Château de Versailles

Palatul Versailles dezvoltă de mulți ani instrumente educative pentru diverse niveluri de învățământ, cu programe speciale de pregătire a vizitei pentru profesori și recent pe pagina sa de Resurse pedagogice http://ressources.chateauversailles.fr/, cu materiale speciale pentru Istoria Artei sau prin pagina Edutheque: resurse pedagogice, culturale și științifice, pentru profesori - https://www.edutheque.fr/utiliser/arts-etlettres/partenaire/chateau-de-versailles.html. 
O astfel de vizită virtuală poate fi un mediu excelent pentru câteva lecții de istoria artei, pentru seminarii despre arhitectura și mobilierul Rococo, pentru un atelier despre lucrările complexe de restaurare și conservare întreprinse de-a lungul anilor de Palatul de la Versailles în urma unor distrugeri sau evenimente, etc. Desigur acestea ar putea fi temele de interes compatibile cu programa UAUIM, dar oferta este și pentru alte profesii din domeniul culturii deosebit de interesantă: literatură, muzică barocă, dramaturgie, teatru, istoria costumului, istorie, politică, etc.

\section{Activități dedicate prin proiectul SCHOLARH 2021}

În acest sens, prin Proiectul SCHOLARH 2021 am organizat și coordonat două activități prin care să familiarizăm mediul universitar al UAUIM cu maniera în care educația clasică și cele mai noi tehnologii în investigarea, intervenția și difuzarea patrimoniului material se pot îmbina echilibrat pentru a aduce în formarea unui arhitect contemporan un plus de acuratețe, un plus de abilități tehnice, o sincronizare cu mediul internațional de specialitate. Desigur, este vorba despre o testare a mediului intern cu tipuri de metode de lucru deja maturizate în mediul universitar de arhitectură internațional.

Digital Heritage_webinar este un seminar online care a avut loc la data de 15 septembrie 2021 pe platforma Zoom (din cauza condițiilor pandemice). La evenimentul desfășurat în limba engleză i-am invitat ca speakeri pe Nicolo Dell'Unto, Paul Chaine, Andra Bria și Ioana Mischie, fiecare dintre noi pregătind o prezentare pe tema patrimoniului arhitectural în relație cu formele de digitizare și digitale ale acestuia, așadar diferite metode prin care acesta poate fi investigat și analizat de către arhitecți, studenți arhitecți și profesioniști în restaurare, dar și diseminat și explorat de către un public mai avizat sau mai larg cu ajutorul unor tehnologii de realitate virtuală sau augmentată.

Nicolo Dell'Unto este conferențiar la Universitatea LUND din Suedia, Departamentul de Arheologie și Istorie Antică, directorul Laboratorului de Arheologie Digitală al instituției și cadru asociat la Departamentul de Management al Colecțiilor, Universitatea din Oslo, Norvegia. Acesta a explicat în prezentarea sa „Virtual Space and Knowledge Production" (Spațiul virtual și producția de cunoaștere) metodele de cercetare digitală și de reconstituire virtuală a unor situri aparținând patrimoniului arheologic mondial - precum Pompeii - sau național -precum situri și artefacte aflate pe teritoriul Suediei, pe care le utilizează în Laboratorul de Arheologie Digitală. Dincolo de aparatura performantă de măsurare și înregistrare in situ, instrumentele de investigare digitale pentru diagnoză și patologie și platforma pentru colecții digitale de artefacte - cu fișe de obiect și informații detaliate - aceste mijloace s-au dovedit esențiale în această perioadă de pandemie, când au servit și ca mediu didactic de studiu și de examinare. De asemenea, utilizarea tehnologiei VR în Laboratorul de Arheologie Digitală al Universității LUND încearcă să ajute studenții și cercetătorii să poată explora reconstituiri ale unor ansambluri arhitecturale de patrimoniu din care astăzi se păstrează doar 
urme arheologice, pentru o mai bună înțelegere a spațialității, modului de viață, elementelor componente, ori detalii precum maniera în care lumina naturală pătrundea, cum era poziționată o anume iconografie, relații funcționale, etc. Pornind așadar de la ideea de „exemplaria graeca" care stă la baza preocupărilor antice pentru patrimoniu, așadar importanța modelului, rolul studiului aprofundat inclusiv prin mediul digital al acestor situri servește cunoașterea, păstrarea și utilizarea (reinterpretarea) unor modele reușite, înțelegerea unor tipologii spațiale adaptate la o anumită epocă și context particulare. Imagini din prezentarea sa sunt comentate în capitolul anterior "Criterii esențiale și metode de lucru cu patrimoniul digitalizat și digital (reconstituirile virtuale după monumente de arhitectură). Autenticitatea".

Colecțiile digitale de artefacte prezentate de profesorul Dell'Unto reprezintă o serie de piese de patrimoniu arheologic de dimensiuni reduse - în acest caz - unelte, vase, arme, etc. - aparținând unui anumit sit și organizate după anumite criterii specifice. Acestea sunt practic scanări 3D sau fotogrammetrii 3D ale obiectelor reale, care pot fi studiate pe platforma online sub forma unor volumetrii tridimensionale, având fiecare o fișă de obiect cu date precise despre măsurători, epocă, stare, material și multe alte detalii. Rolul acestor colecții este de a organiza asemeni colecțiilor fizice de muzeu o anumită serie de piese care provin din același loc sau au un criteriu de specialitate comun, pentru a exista și o arhivă sub formă digitală care să le prezerve (Fig. 4).

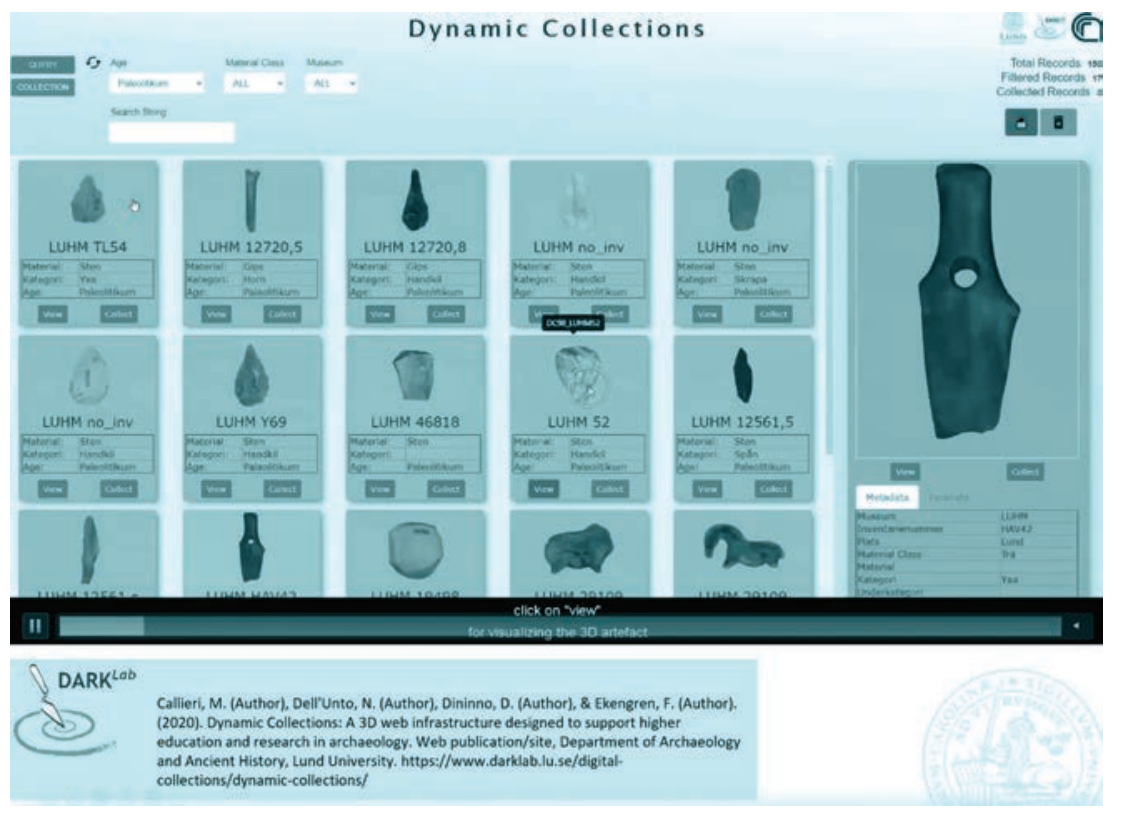

Fig. 4. Imagine cu Colecția Dinamică de artefacte a Laboratorului de Arheologie Digitală, LUND.

Volumetriile sunt obținute prin fotogrammetrie 3D, agregate cu ajutorul unor softuri și apoi încărcate pe această platformă interactivă, utilizată incluisv la examinarea studenților pe durata pandemiei.

Sursa imaginii: https://models.darklab.lu.se/dynmcoll/Dynamic_Collections/ 
Paul Chaine este șeful Departamentului Digital al Palatului Versailles, profesor la Sciences Po Paris și ESCP Business School, iar prezentarea sa în cadrul Digital Heritage_webinar a fost despre modul în care cu ajutorul noilor tehnologii digitale, Palatul Versailles - monument de arhitectură cunoscut la nivel mondial - se deschide spre vizitatori virtuali, spre un public diversificat și amplificat. Prezentarea sa a purtat tiltul de „VR/AR in Versailles, a tool to address all audiences” (VR/AR în Versailles, un instrument care să se adreseze întregului public"). Aplicația de realitate virtuală dezvoltată în 2019 în parteneriat cu Google Arts \& Culture, „VersaillesVR: the Palace is Yours”, prezentată în capitolul anterior este un prim pas spre un proiect mai amplu al instituției, cu mai multe tipuri de produse digitale care să ajute la explorarea și educația cu ajutorul acestor tehnologii, atât VR, cât și AR. Așadar aceste produse care sunt parțial bazate pe surse analoage convertite în format digital și parțial pe surse născute digital, gândite atât cu rolul de difuzare și democratizare a cunoașterii spre un public mare, cât și în scop didactic de la nivel de învățământ primar până la superior.

Am invitat acești doi profesori cu prezentări ale experienței internaționale de ultimă oră pe această temă a patrimoniului digitalizat și digital, spre mediul academic al UAUIM - studenți, doctoranzi și cadre didactice - pentru a împărtăși stadiul actual al unor tipuri de demersuri culturale și educaționale, dar și de a crea noi oportunități de colaborare în viitor.

În completarea experienței franceze și sudeze, cele două invitate din România, Andra Bria - fondator al Craft Product School și Ioana Mischie au adus un plus prin experiența autohtonă în utilizarea tehnologiei de VR pentru patrimoniul cultural în general, inclusiv un proiect de universitate digitală în realitate virtuală: OmniversityVR - https://omniversity. app/. Experiența lor în proiecte internaționale transdiciplinare, de la cinematografie la teme de arhitectură, sociologie și politică, reprezintă o privire proaspătă și ne-a demonstrat cum ne putem adapta la o societate a viitorului.

Webinarul a încercat să creeze un schimb de experiență virtuală, de idei, o dezbatere vie, o oportunitate de a lega relații profesionale între toți participanții, o punte spre viitoare proiecte internaționale.

Digital Heritage_lab este un workshop desfășurat cu prezență fizică, dar și cu participare online a invitaților internaționali, un format hibrid care vine în completarea Digital Heritage_webinar. Invitații au fost cei doi profesori străini de la webinar - Nicolo Dell'Unto, și Paul Chaine - alături de prof.dr.habil.arh. Hanna Derer de la Departamentul de Istoria și Teoria Arhitecturii și Conservarea Patrimoniului - specialist recunoscut - și arh. Loredana Stasisin creatoarea Stasisin Services, inițiatoarea proiectului "Case care plâng" și acum profesionist activ în domeniul patrimoniului cultural digitalizat, autoare de tururi și expoziții virtuale. Prof. Derer a deschis pentru participanții înscriși la workshop - studenți la Facultatea de Arhitectură, Interior și Urbanism, dar și doctoranzi sau stagiari - tema responsabilității în lucrul cu aceste forme de patrimoniu digitalizat și digital. Loredana Stasisin a prezentat experiențe 
profesionale individuale în legătură cu diferite proiecte de digitalizare a patrimoniului arhitectural și direcții posibile de dezvoltare a muzeelor în epoca digitală.

Acest workshop desfășurat în Atelierul Experimental „MAC POPESCU" (HighTech Learning Centre) din UAUIM în perioada 20-24 septembrie 2021 este transpunerea în practică a elementelor de teorie și metodă prezentate în Digital Heritage_webinar.

\section{Temă}

Activitatea propune explorarea uneia dintre tehnicile de înregistrare a artefactelor de patrimoniu - fotogrammetria, oportunitatea de a lucra cu soft-uri de ultimă oră și iniția o mică bază de date de specialitate: o colecție digitală.

Concret tema poartă numele de "Colecție de încuietori istorice" și presupune selecția unui studiu de caz individual de către fiecare participant. Criteriile de selecție sunt: condiția de a fi o încuietoare aparținând unui stil istoric reprezentativ și unui monument de arhitectură (dar nu obligatoriu) pentru București (sau orașul în care se află participanții online), să se afle la exterior - deci la o ușă de intrare, accesibilă pentru fotografii de detaliu și de a reprezenta o „ancoră afectivă". De ce un astfel de obiect ca temă ? Ideea este de a fi un obiect de dimensiuni rezonabile pentru durata workshop-ului, aflat la o înălțime potrivită și accesibilă pentru fotografie, de a putea fi fotografiat din toate unghiurile și de a fi reprezentativ pentru clădirea căruia îi aparține. De asemenea, patina și elementele de detaliu de pe un astfel de obiect ne vorbesc despre istoria sa, despre simboluri și stil, despre importanța clădirii în timp, despre modul de folosire de către cei ce au trecut pragul acestor clădiri, despre grija sau neglijența cu care sunt tratate.

\section{Obiectiv}

Familiarizarea și formarea unor studenți, doctoranzi și stagiari arhitecți cu o metodă de lucru și colaborare, în care să exerseze atât autonomia deciziilor, cât și cooperarea în echipă sunt esențiale. Cunoștințele teoretice de istoria arhitecturii și protecția patrimoniului sunt exersate prin partea de selecție individuală argumentată a studiului de caz și apoi prin prezentarea finală, contextualizată. Abilitățile tehnice sunt probate prin participarea la instruirea practică și demonstrațiile asigurate de coordonatorul tehnic - conf.dr.arh. Andreea Iosif, Atelierul Experimental "MAC POPESCU". Partea practică constă în mersul pe teren, colectarea fotografiilor necesare (200-500 de imagini din toate unghiurile), agregarea modelului 3D și în final compunerea fișei, inserarea în colecția 3D online și realizarea afișului.

Capacitatea de a realiza ceva concret la finalul workshop-ului în urma instruirii este completată de abilitatea de a înțelege și pune în valoare un artefact de patrimoniu, de a semnala un caz de monument în pericol, de a promova o clădire reprezentativă uitată, de a aduce informații noi despre un proiect, dar și de a-l prezenta prin 3D-ul rezultat și printrun afiș format A1. Pentru un arhitect sunt importante atât partea de 
conținut, cât și cea de reprezentare grafică și estetică - în acord cu stilul arhitectural de care aparține obiectul și cu scopul afișului, dar și cea de comunicare și susținere.

\section{Coordonatori}

Alături de mine, coordonarea tehnică a fost asigurată de conf.dr.arh. Andreea Iosif, de altfel și coordonatoarea Atelierului Experimental "MAC POPESCU”, Andra Bria și Ioana Mischie.

Jurizarea lucrărilor a fost realizată de către Andra Bria, Ioana Mischie, Nicolo dell'Unto și Paul Chaine.

\section{Metodă}

Workshop-ul a fost gândit să exerseze deopotrivă lucrul individual autonom, cât și pregătirea unei colecții de artefacte digitale în echipă.

Participanții au avut un program clar în cele cinci zile de workshop, în care gradual, de la explicarea temei, la investigație individuală pe teren, instruire tehnică și îndrumare constantă în Atelierul Experimental, au învățat tehnica fotogrammetriei $3 \mathrm{D}$, au beneficiat de demonstrații cu soft-urile utilizate, din care menționăm RealityCapture și platforma SketchFab, au creat împreună o primă colecție digitală de obiecte cu fișă de obiect și la final un afiș (poster).

Condiția prealabilă de înscriere a presupus familiarizarea cu tema patrimoniului digital prin participarea la Digital Heritage_webinar, posibilitatea de a utiliza propriul smartphone pentru colectarea sutelor de fotografii pe teren și abilități tehnice de lucru cu soft-uri noi.

Cele mai bune trei proiecte compuse fiecare din fotogrammetria 3D, fișa de artefact și afișul - au fost premiate cu premii de la Cărturești și toți participanții au primit diplome de participare, semnate de membrii juriului și de către Rectorul UAUIM.

Criteriile de apreciere ale proiectelor au fost pentru fiecare dintre cele trei componente calitatea realizării tehnice, dar și capacitatea de a contextualiza cazul ales, de a observa caracteristicile stilului arhitectural istoric de care aparține (specific Bucureștiului) - de la Clasicism la Modernism - de a pune în valoare aceste obiecte de patrimoniu inclusiv la nivel de compoziție, conținut și estetică a afișului, dar și abilitatea de a comunica observațiile și rezultatele acestei mici cercetări prin susținerea proiectului la final (Fig. 5, 6, 7, 8).

Workshop-ul are o pagină de Facebook https://fb.me/e/16XvI1tX1, iar obiectele obținute prin fotogrammetria 3D sunt încărcate pe platforma online SketchFab.

Participanții au demonstrat atât abilități tehnice și cunoștințe de istoria arhitecturii aplicate concret pe un studiu de caz, dar și sensibilitate și conștientizarea unei misiuni și responsabilități ca profesionist în domeniul arhitecturii sau urbanismului în intervenția pe patrimoniu. 


\section{Rezultate}

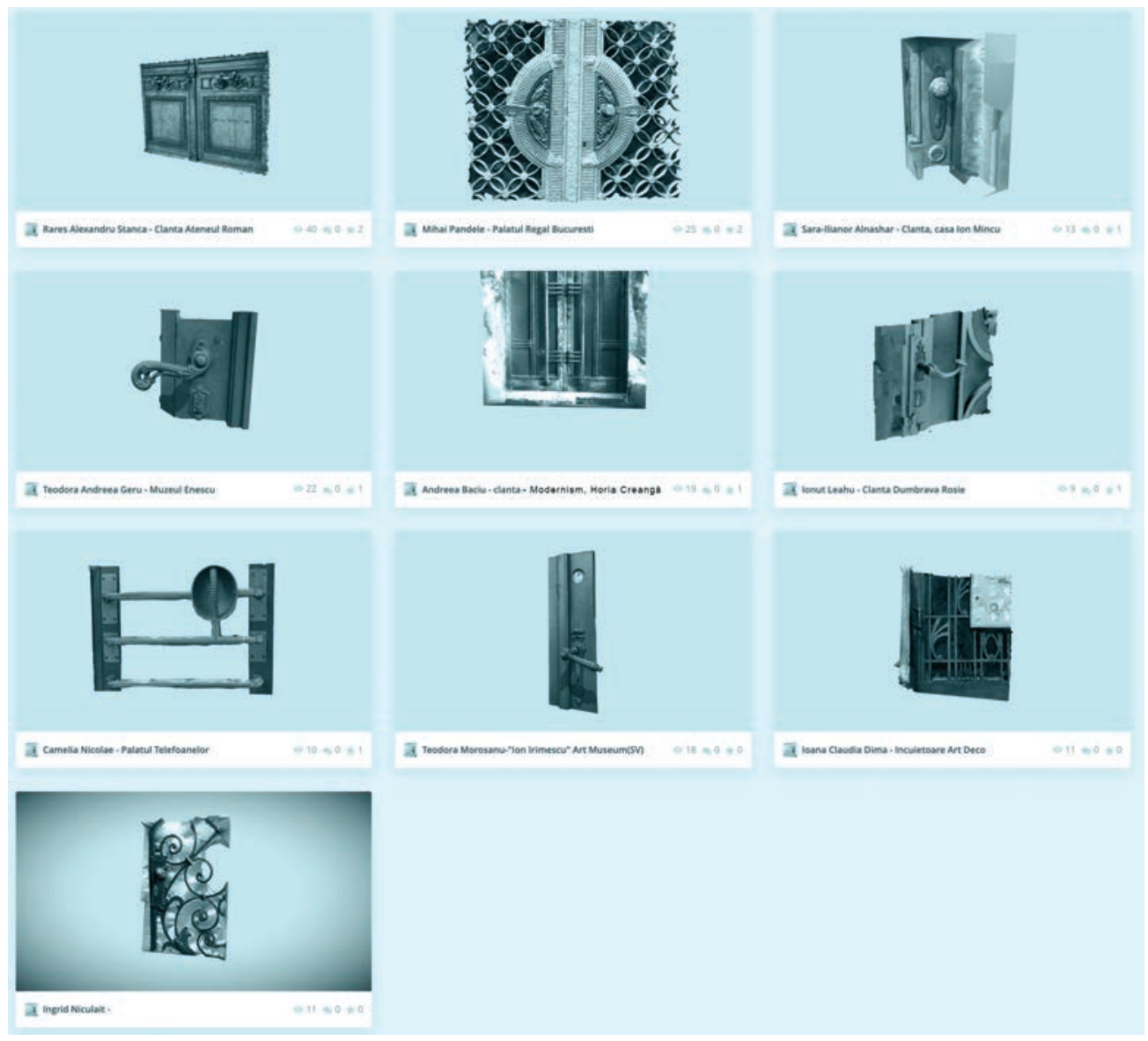

Fig. 5. Colecția digitală de „Încuietori de patrimoniu” pe platforma digitală Sketchfab. Sursa imaginii: https://sketchfab.com/virtualia.uauim 


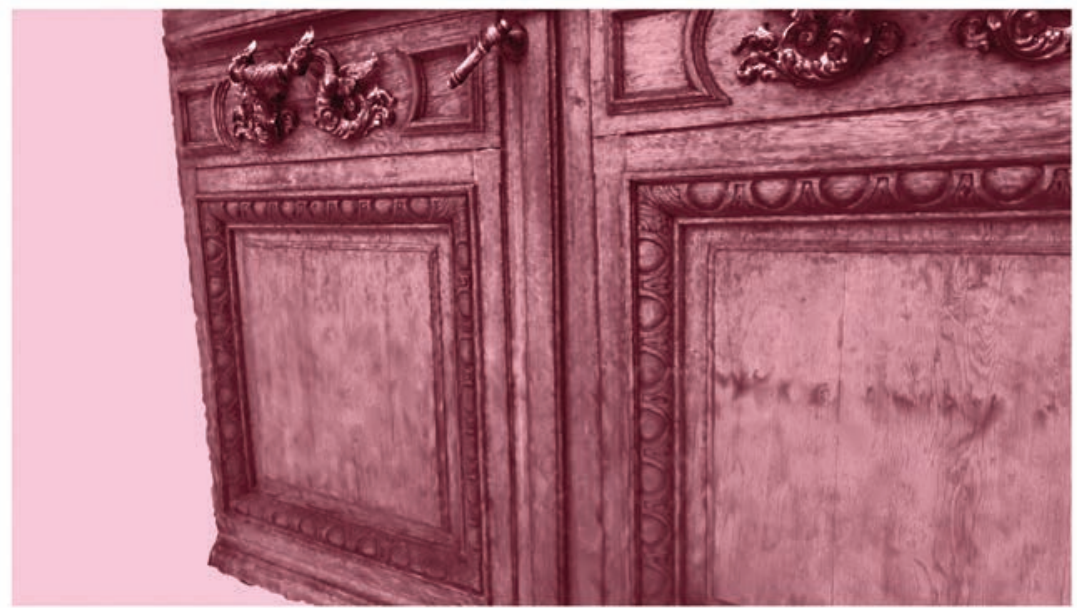

Rares Alexandru Stanca - Clanta Ateneul Roman

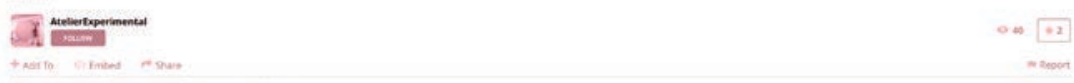

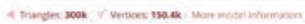

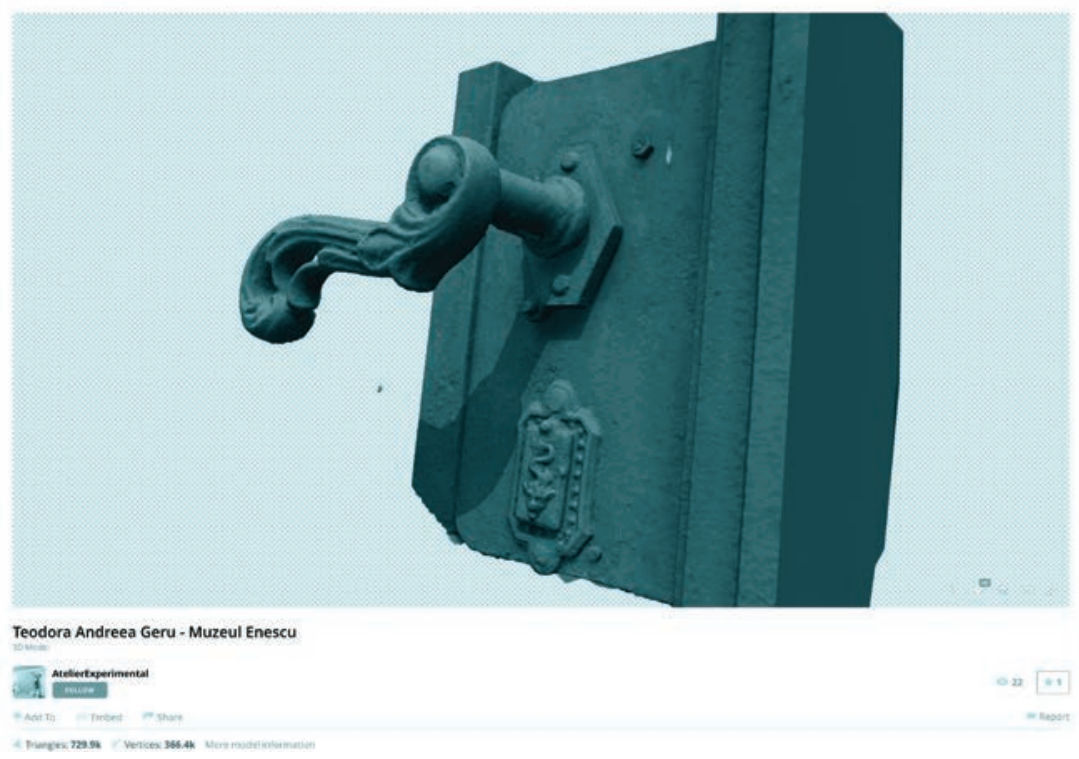

Fig. 6. Detalii a două studii de caz: intrarea principală a Ateneului Român și cea a Muzeului Enescu, București, Digital Heritage_lab. Se poate observa calitatea bună a fotogrammetriilor 3D, realizate într-un timp foarte scurt. Sursa imaginilor: https:// sketchfab.com/virtualia.uauim 
Fig. 7. Afis pentru încuietoarea ușii principale a Palatului Telefoanelor, București, Digital Heritage_lab. Autor Camelia Nicolae, UAUIM.
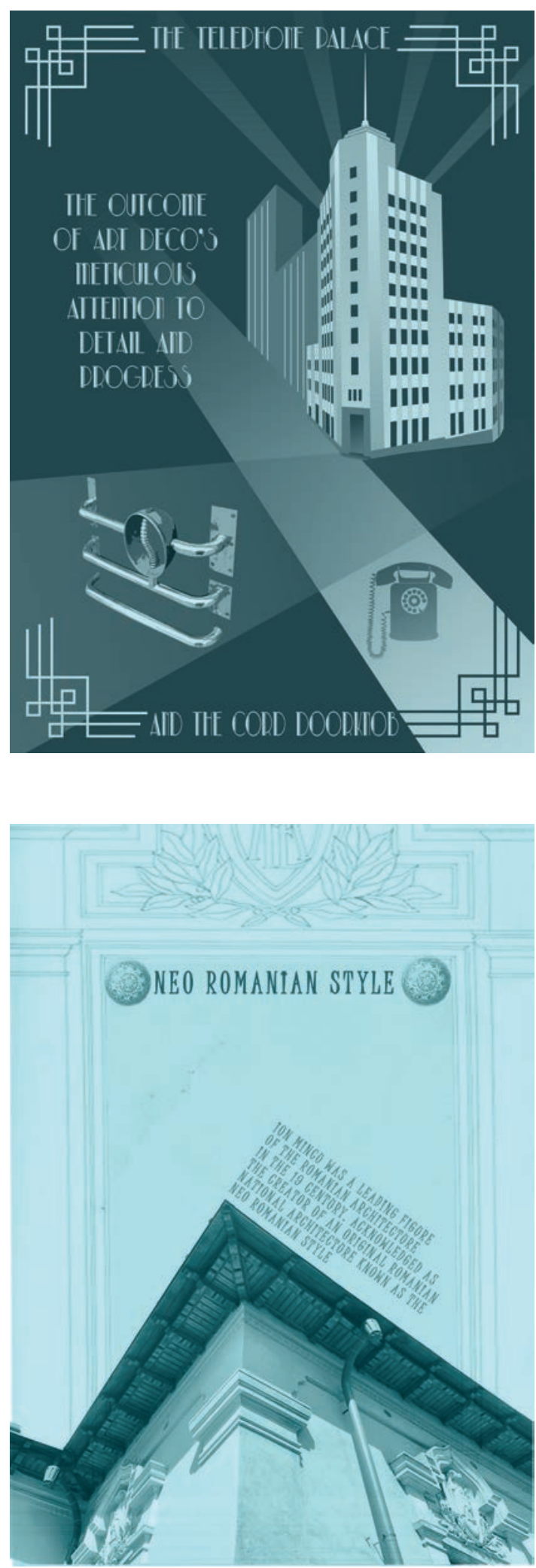

Fig. 8. Afiș pentru încuietoarea de la ușa secundară a Casei Ion Mincu, București, Digital Heritage_lab. Autor: Sara-Ilianor Alnashar. 


\section{Concluzii}

Ghidul de față reprezintă atât o expunere teoretică, cât și o reflectare prin creații concrete și activități practice a câtorva dintre ipostazele contemporane ale relației patrimoniu arhitectural - tehnologii digitale, care pot fi utile pentru mediul academic de specialitate și pentru practica profesională.

Astfel de platforme digitale create pentru mediul universitar din UAUIM pot fi utile pentru cercetătile doctorale, pentru proiectele de atelier de restaurare, lucrul în echipe și colaborări internaționale de la distanță.

În acest sens, în cadrul Centrului de Studii de Arhitectură Vernaculară pe care îl coordonez am inițiat în 2017 CSAV Lab - un laborator dedicat patrimoniului - în care am organizat un training cu soft-ul GIS printr-o sponsorizare din partea ESRI România - Environmental Systems Research Institute, prin care instructorii invitați au pregătit reprezentanți din fiecare departament al UAUIM, cărora li s-au acordat certificate de recunoaștere și licențe personale. Obiectivul a fost de a utiliza acest soft pentru cartarea patrimoniului (vernacular) de pe teritoriul autohton, de a disemina această tehnologie cu potențial spre toate departamentele, de a crea o platformă digitală pe care să se poată colabora de la distanță la proiecte de cercetare comune.

Această etapă vine abia acum, în 2021, când în urma celor două activități coordonate menționate mai sus - Digital Heritage_webinar și Digital Heritage_lab - am inițiat, pe site-ul CSAV, platforma CSAV Heritage Lab, care va utiliza softurile prezentate în studiile de caz de mai sus: www.csav.ro.

Acest articol-ghid încearcă să prezinte obiectiv diferitele proiecte și inițiative, arătând totodată potențialul, dar și limitările (de moment) ale acestor instrumente de cercetare și explorare. De asemenea, dezvoltarea unei metode de cercetare și lucru este importantă pentru a păstra un grad de valoare și autenticitate cât mai ridicat atât pentru formele digitizate, cât și reconstituirile digitale de obiect ori ansamblu de patrimoniu arhitectural.

Privind din perspectiva arhitectului, dar și al îndrumătorului de proiecte de restaurare și conservare, formarea continuă și dezvoltarea de noi abilități în lucrul cu patrimoniul sunt esențiale pentru a fi competitiv și a rămâne relevant profesional. 


\section{Referințe}

Brandi, C. (2005). Theory of Restoration, Trad. Rockwell, C., Nardini Editore, Istituto Centrale per il Restauro, Firenze.

Correia, M., Alcindor, M., Carlos, G.D., Rocha e Sousa, S., Mileto, C., Vegas, F., Cristini, V. (2O21) World Heritage, vernacular dwellings and digitalisation: The case of the Fortified Churches in Transylvania, Romania / Patrimoniul Mondial, locuințele vernaculare și digitalizarea: Cazul Bisericilor Fortificate în Transylvania, România, CSAV Journal 2020, Editura Universitară „Ion Mincu”, 2021: https://csav.ro/2020/ csav-journal-2020_full-digital-version/, consultat la 15 octombrie 2021.

Criticos, M. (2021). Limbaj Arhitectural (2), Tematică și bibliografie, (curs și seminarii anul II, UAUIM), https://www.uauim.ro/facultati/arhitectura/arhitectura/disciplineobligatorii/it-6/, consultat la 5 octombrie 2021.

Dale, Edgar. (1969). Audio-visual methods in Teaching. (3rd ed). New York: The Dryden Press, https://openlibrary.org/works/OL1375812W/Audio-visual_methods_in_ teaching.

Demetrescu, E., Ferdani, D., Dell'Unto, N., Leander Touati, A.M., Lindgren, St. (2016). Reconstructing the original splendour of the House of Caecilius Iucundus. A complete methodology for virtual archeology aimed at digital exhibition, articol în SCiRES, vol.6, http://www.sciresit.it/article/view/12009/11022, consultat la 1 septembrie $2 \mathrm{O} 21$.

Jokilehto, J. (2018). A History of Architectural Conservation, Second Edition, Editura Routledge, Taylor \& Francis Group, New York, S.U.A.

Sfinteș, A., Mitrea, A., Moleavin A., Zacharias Vultur, I. (2020). Metode și tehnici specifice de cercetare în arhitectură, https://www.uauim.ro/cercetare/scholarh/ Brosura\%2Odigitala\%2OSCHOLARH.pdf, consultată la data de 10 iulie 2021.

Zacharias Vultur, I. (2012). Metafora mașinii în discursul modern de arhitectură. Norman Bel Geddes și Le Corbusier, (teză de doctorat), Biblioteca UAUIM

Zacharias Vultur, I. (2018). Bucharest: Towards a Rethinking of the Urban Heritage, articol în The IAFOR Conference on Heritage \& the City - New York 2018, Official Conference Proceedings, https://papers.iafor.org/wp-content/uploads/papers/ hcny2O18/HCNY2O18_44556.pdf, consultat la data de 25 septembrie 2021.

Zahariade, A.M., Brătuleanu, A. (2008). Introducere în arhitectura contemporană. Note de curs și addenda bibliografică, (anul I, UAUIM), Editura Universitară „Ion Mincu, București

***. (2009). Charter on the Preservation of the Digital Heritage, United Nations Educational, Scientific and Cultural Organization, Organisation des Nations Unies pour l'éducation, la science et la culture, unesdoc.unesco.org/in/rest/annotationSVC/ DownloadWatermarkedAttachment/attach_import_a73559e3-c94e-4877-8a53dc43d9dfdf58?_=179529eng.pdf\&to=5\&from=1, consultată la data de 1 Iulie 2021.

***. (2O21). Concept of Digital Heritage, site-ul UNESCO, https://en.unesco.org/ themes/information-preservation/digital-heritage/concept-digital-heritage, consultat la 5 septembrie 2021. 